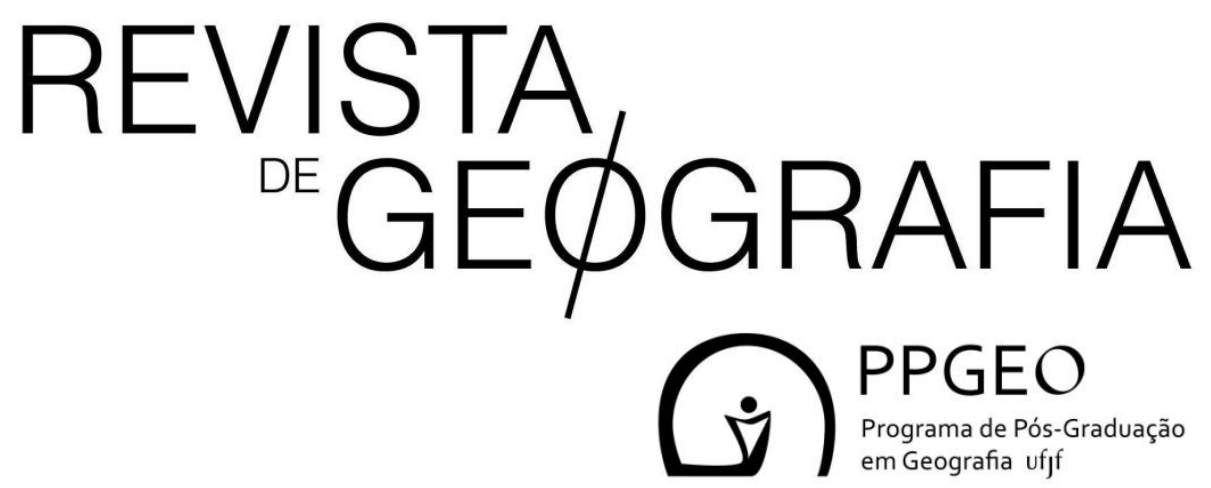

\title{
ANÁLISE DOS SIGNIFICADOS POLÍTICO-IDENTITÁRIOS DOS MONUMENTOS NA PRAÇA DOS GIRASSÓIS, EM PALMAS, TO
}

\section{ANALYSYS OF THE POLITICAL-IDENTITARY MEANINGS OF MONUMENTS FROM} "PRAÇA DOS GIRASSÓIS" (SUNFLOWER SQUARE"), IN PALMAS, TO

Wesley Lima

Universidade Federal do Tocantins (UFT) Quadra 109 Norte Avenida NS 15, Plano Diretor Norte, Palmas - TO E-mail: lima.wesley@uft.edu.br

Kelly Bessa

Universidade Federal do Tocantins (UFT) Quadra 109 Norte Avenida NS 15, Plano Diretor Norte, Palmas - TO E-mail:kellybessa@uft.edu.br 


\title{
Resumo
}

Este artigo tem como objetivo identificar os significados políticos-identitários dos principais monumentos edificados na Praça dos Girassóis em Palmas - TO, bem como analisar as intenções e os sentidos desses monumentos no período em que foram instalados. Para tanto, com o suporte de dados documentais, pesquisa em campo e revisão bibliográfica da literatura sobre o tema, tem-se, no primeiro momento, uma descrição detalhada da localização, do ano de implantação e da dimensão espacial desses monumentos; já no segundo momento, elabora-se uma análise reflexiva acerca dos significados atribuídos a essas obras, destacando sua plurivocalidade e a construção desse espaço simbólico para o devir da cidade e dos sujeitos que a ocupam. Os resultados da análise mostram que os monumentos da Praça dos Girassóis foram todos construídos durante a gestão governamental de José Wilson Siqueira Campos, e conclui que estas formas simbólicas espaciais expressam a construção de uma memória para o futuro, associada à imagem do primeiro governador do estado, além de serem portadoras de simbolismos e de autorrepresentação ou autoafirmação política.

Palavras-chaves: Monumentos. Simbologia. Identidade. Religião.

\begin{abstract}
This article aims to identify the political-identity meanings of the main monuments built at Praça dos Girassóis (Sunflower Square) in Palmas-TO, as well as to analyze the intentions and meanings of these monuments in the period in which they were installed. For this purpose, with the support of documentary data, field research and bibliographic review of the literature on the subject, there is, in the first moment: a detailed description of the location, year of implantation and the spatial dimension of the monuments of the Square; in the second moment, a reflexive analysis is elaborated about the meanings attributed to these constructions, highlighting their plurivocality and the construction of this symbolic space for the future of the city and the subjects that occupy it. The results of the analysis show that the monuments of Sunflower Square were all built during the governmental management of José Wilson Siqueira Campos, moreover conclude that these spatial symbolic forms express the construction of a memory for the future, associated with the image of the first governor of the state, as well as these forms are bearers of symbolism and self-representation or political self-affirmation.
\end{abstract}

Keywords: Monuments. Symbology. Identity. Religion.

\section{Introdução}

Nesta pesquisa, objetiva-se entender os significados e as dimensões política e identitário-religiosa dos monumentos inseridos na Praça dos Girassóis em Palmas, no Tocantins, a saber: o Memorial da Primeira Missa, o Cruzeiro, e os monumentos Cascata, Relógio do Sol, Bíblia, Dezoito do Forte de Copacabana e Súplica dos Pioneiros. Para tanto, busca-se, além de descrever tais monumentos, identificar seus sentidos e suas intenções, considerando o momento da implantação e a identificação dos idealizadores.

Inicialmente, é adequado destacar e conceituar o termo monumento. Para Le Goff (2003, p. 95), "uma obra comemorativa, uma escultura: arco triunfo, coluna, troféu, pórtico e entre outras estruturas", são construções regularmente consideradas monumentos. Le Goff

ISSN: 2236-837X 
(2003) define como monumento tudo aquilo que consegue lembrar o passado, perpetuando e fazendo recordar à memória.

Nesse mesmo sentido, Choay (2001) argumenta que os monumentos atuam diretamente sobre a memória, convocando e fazendo vibrar um passado como se fosse presente. Esse passado convocado pelas simbologias expressas nos monumentos "não é um passado qualquer, é localizado e selecionado para fins vitais, na medida em que pode, de forma direta, contribuir para manter e preservar a identidade de um grupo" (CHOAY, 2001 , p. 18). A essa questão acrescenta-se que os monumentos são interpretados como um conjunto de bens materiais que articulam referências às identidades, associam elementos simbólicos e fazem alusão às identidades locais ou regionais (CHOAY, 2001). Por outro lado, são percebidos como "sintomas" de nossas experiências no tempo (HARTOG, 2003).

Os monumentos são assim, construções que podem fazer parte de um projeto político-identitário. Peet (1996, p. 23), sobre isso, indica que "as elites, por exemplo, constroem monumentos visando expressar e ratificar seus valores e exibir o poder que detêm". Por sua vez, Corrêa (2018, p. 174) argumenta que "estátuas, obeliscos, templos, memoriais, entre outras formas simbólicas espaciais, que consideramos como monumentos, constituem [...] importantes meios visuais por intermédio dos quais mensagens associadas à identidade, poder e continuidade de valores são comunicadas". Assim, utilizada como portadores de mensagens de cunho ideologicamente político, religioso e identitário, a construção de monumentos objetiva "o fortalecimento de identidades em baixa [...] ou que ainda necessitam ser criadas e enfatizadas" (CORREAA, 2013, p. 75).

Desse modo, para Corrêa (2013, p.74), os monumentos "[...] são exemplos de formas simbólicas espaciais", que se distinguem por representar a vivência da experiência humana no espaço, sendo, portanto, dotadas de uma espacialidade, que se torna carregada de sentidos e significados. Estes conduzem valores para o devir do lugar, da cidade, do espaço, no que se refere à memória e à identidade de seus habitantes (CORRÊA, 2005).

Nessa perspectiva, os monumentos construídos e localizados na Praça dos Girassóis, em Palmas, podem ser interpretados como uma espécie de texto, devido ao "contexto de sua elaboração, significação e difusão" (ZIPPNOTTI, 2014, p. 35). Consequentemente, os monumentos dispersos nessa citada praça exemplificam a articulação política que visa legitimar uma determinada estrutura de poder, porque "as intenções e as tensões conferem às formas simbólicas seu sentido político, atribuindo-lhes o caráter de texto" (CORRÊA, 2018, p.225).

ISSN: 2236-837X 
Além disso, às formas simbólicas espaciais também se conferem marcações de valores religiosos, identitários e culturais que são atribuídos em decorrência, principalmente, da localização, do itinerário, da escala e da visibilidade que cada uma apresenta no espaço. De acordo com Rodrigues (2008), a Praça dos Girassóis é moldada para ser um espaço de legitimação e objetivação, que busca representar a identidade, a cultura e a religião do palmense, do tocantinense. Ademais, enfatiza-se que "as formas simbólicas são elementos fundamentais para marcar a identidade dos grupos com o território" (CORREAA, 2018, p. 240), seja de uma cidade, seja de um estado. Essa marcação pode ser construída ou forjada a partir de um projeto político que vise solidificar ações que devem ser mantidas e perduradas no tempo e no espaço. Por isso, a objetivação desse espaço simbólico perpassa por ações políticas que visam emoldurar ideias e valores para além do tempo presente.

Nesse sentido, esse artigo fornece a descrição desses principais monumentos inseridos na Praça dos Girassóis, seguida pela análise e pela identificação das intenções e dos seus sentidos políticos-identitários, considerando, principalmente, seus idealizadores e o momento da implantação. Por fim, apresenta uma análise reflexiva dos significados políticos, religiosos e identitários relacionados a esses monumentos.

\section{Os monumentos na Praça dos Girassóis: localização, construção e dimensão escalar}

Na Praça dos Girassóis, há um conjunto de monumentos (Quadro 1 e Figura 1), que foram, intencionalmente, encravados nesse espaço a partir de 1989. Porém, na periodização de instalação, notam-se marcações temporais específicas que se associam ao ex-governador desse estado, José Wilson Siqueira Campos, sobretudo nos seus primeiro (1989 a 1991) e terceiro (1999 a 2003) mandatos (Quadro 1).

\begin{tabular}{|c|c|c|c|c|}
\hline \multicolumn{5}{|c|}{ Quadro 1. Palmas: Principais Monumentos na Praça dos Girassóis } \\
\hline Monumentos & $\begin{array}{c}\text { Ano de } \\
\text { instalação }\end{array}$ & $\begin{array}{c}\text { Governador em } \\
\text { exercício }\end{array}$ & Artista/Projetista & Dimensão \\
\hline $\begin{array}{l}\text { Memorial da } \\
\text { Primeira Missa, o } \\
\text { Cruzeiro }\end{array}$ & $\begin{array}{l}18 \text { de maio } \\
\text { de } 1989\end{array}$ & $\begin{array}{c}\text { José Wilson } \\
\text { Siqueira Campos } \\
(1989-1991)\end{array}$ & Arnildo Antunes & $185 \mathrm{~m}^{2}$ \\
\hline Monumento Cascata & 2000 & $\begin{array}{c}\text { José Wilson } \\
\text { Siqueira Campos } \\
(1989-1991)\end{array}$ & João Devair & $1.200 \mathrm{~m}^{2}$ \\
\hline $\begin{array}{l}\text { Monumento Relógio } \\
\text { do Sol }\end{array}$ & $\begin{array}{c}07 \text { de } \\
\text { setembro de } \\
2000\end{array}$ & $\begin{array}{c}\text { José Wilson } \\
\text { Siquera Campos } \\
(1999-2003)\end{array}$ & $\begin{array}{l}\text { Silênio M. } \\
\text { Camargo }\end{array}$ & $\begin{array}{l}700 \mathrm{~m}^{2} \\
\text { aprox. }\end{array}$ \\
\hline Monumento à Bíblia & $\begin{array}{c}10 \text { de } \\
\text { dezembro de } \\
2000\end{array}$ & $\begin{array}{c}\text { José Wilson } \\
\text { Siquera Campos } \\
(1999-2003)\end{array}$ & Nada consta & $7 \mathrm{~m}^{2}$ aprox. \\
\hline
\end{tabular}

ISSN: 2236-837X 


\begin{tabular}{|l|c|c|c|c|}
\hline $\begin{array}{l}\text { Monumento aos } \\
\text { Dezoito do Forte de } \\
\text { Copacabana }\end{array}$ & $\begin{array}{c}05 \text { de outubro } \\
\text { de } 2001\end{array}$ & $\begin{array}{c}\text { José Wilson } \\
\text { Siquera Campos } \\
(1999-2003)\end{array}$ & Mauricio Bentes & $\begin{array}{c}1.638,04 \mathrm{~m}^{2} \\
\text { aprox. }\end{array}$ \\
\hline $\begin{array}{l}\text { Monumento Súplica } \\
\text { dos Pioneiros }\end{array}$ & $\begin{array}{c}18 \text { de março } \\
\text { de } 2002\end{array}$ & $\begin{array}{c}\text { José Wilson } \\
\text { Siquera Campos } \\
(1999-2003)\end{array}$ & Mauricio Bentes & $67,55 \mathrm{~m}^{2}$ \\
\hline
\end{tabular}

Fonte: Tocantins, 2013.

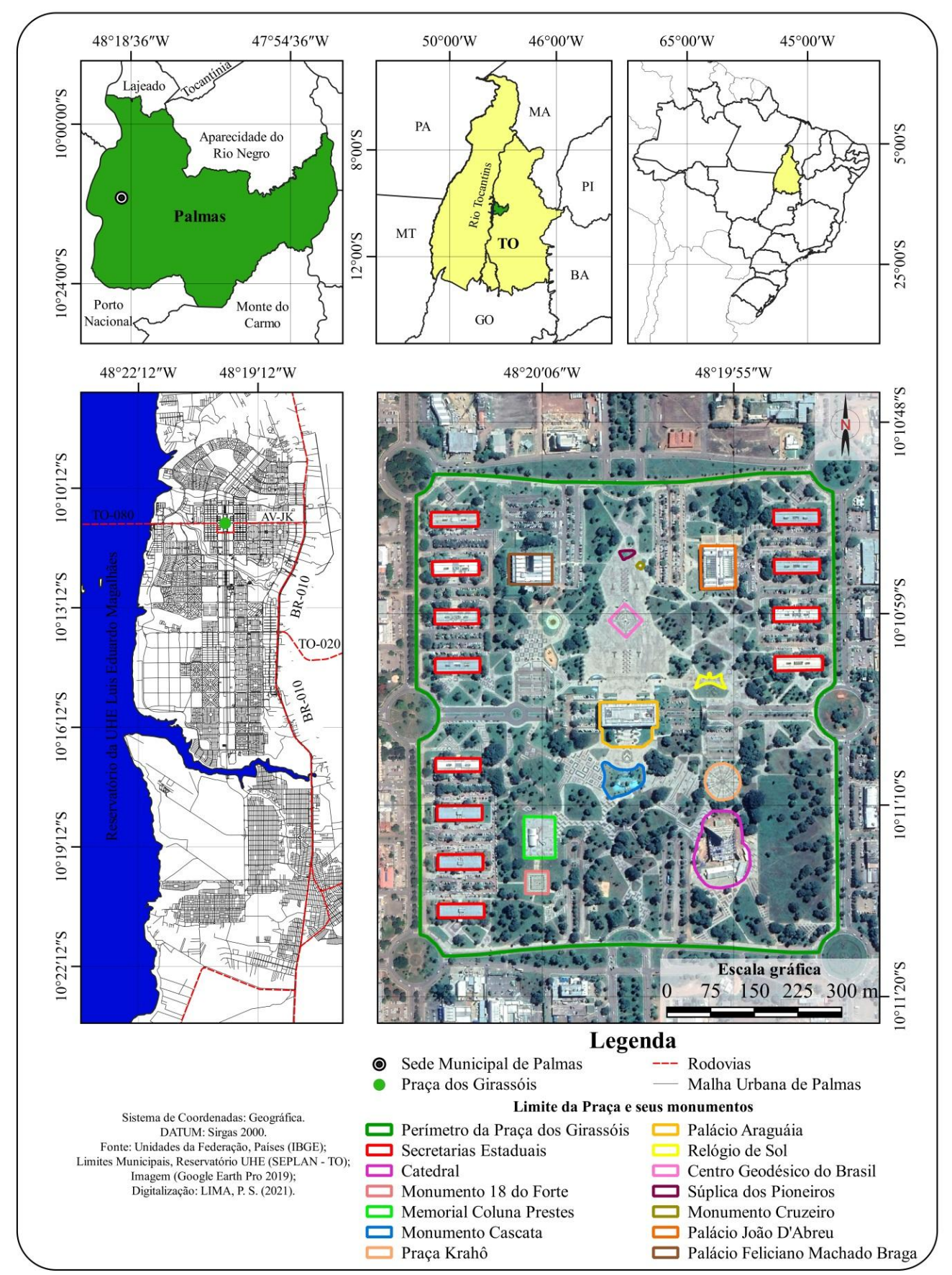

Figura 1 - Praça dos Girassóis: Distribuição espacial dos monumentos e edifícios Fonte: IBGE, 2020. SEPLAN-TO, 2020. Edição e organização: Lima, P. S, 2021. 
Considerado o primeiro monumento erigido na cidade de Palmas, o Cruzeiro (Figura 2) foi instalado no dia 18 de maio de 1989, no lugar notabilizado como marco zero da capital e da Praça dos Girassóis. Nessa data, ocorreu também a primeira missa em solo tocantinense, celebrada pelo Bispo Celson Pereira, contando com a presença do primeiro governador Siqueira Campos. Esse monumento foi esculpido em madeira extraída do paubrasil pelo artesão Arnildo Antunes (TOCANTINS, 2013) e conta com um símbolo cravado em seu centro: o mapa do novo estado do Tocantins, com a representação de duas mãos para o alto (Figura 3).

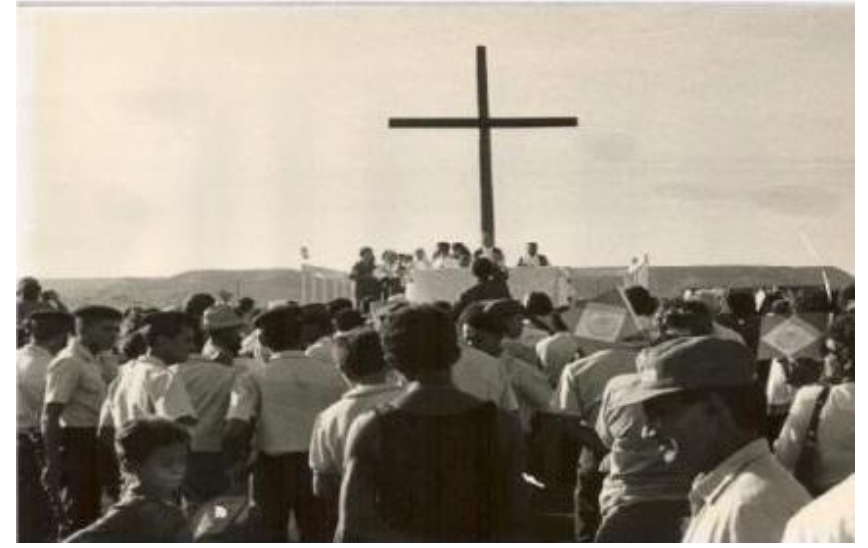

Figura 2 - Palmas: primeira missa celebrada na capital do Tocantins, 1989

Fonte: Marcio Di Pietro, 1989.

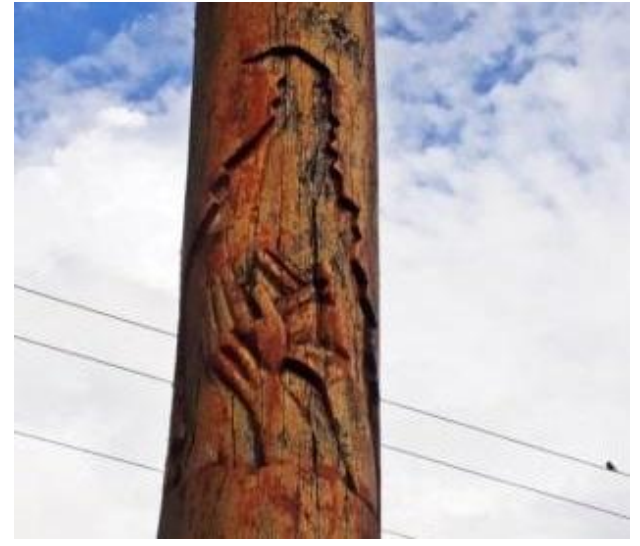

Figura 3 - Palmas: inscrição no Cruzeiro: mapa do Tocantins e duas mãos erguidas Fonte: Lima, 2020.

O Cruzeiro encontra-se fincado na Praça dos Girassóis, na entrada principal do Palácio Araguaia, há cerca de 32 anos com o mesmo material com que fora construído. Em 2016, esse monumento passou por uma reforma, obtendo uma base de metal no seu interior, como forma de garantir sua permanência e conservação (DIAS, 2016). Ademais, conta com uma dimensão escalar de aproximadamente 9 metros de altura por 2,20 metros de comprimento, ocupando uma área de quase 185 metros quadrados (Figuras 4 e 5). Por meio do Decreto Municipal $n^{\circ} 22$, de 29 de fevereiro de 2000 (PALMAS, 2000), o Cruzeiro tornou-se um patrimônio cultural tombado, obtendo, assim, seu valor cultural oficializado na capital tocantinense (TOCANTINS, 2013). 


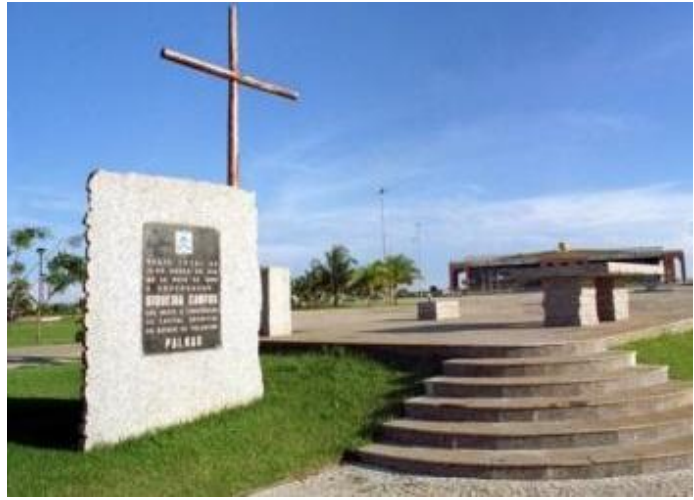

Figura 4 - Praça dos Girassóis: Monumento o Cruzeiro e a fachada do Palácio Araguaia Fonte: Márcio Di Pietro, 2004.

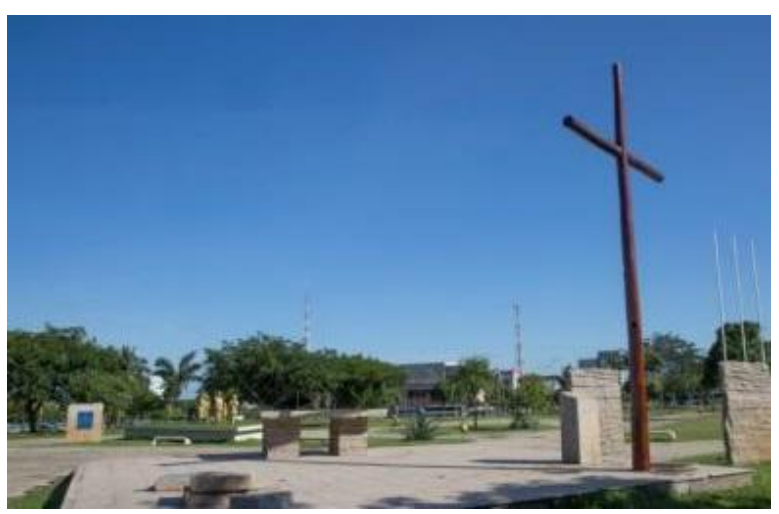

Figura 5 - Praça dos Girassóis: Monumento o Cruzeiro e o Monumento Súplica dos Pioneiros Fonte: Flávio André de Sousa, 2018.

A partir de 1998, no segundo mandato de Siqueira Campos como governador do Tocantins, a Praça dos Girassóis passou por uma reforma. Nesta reforma, instalaram-se novos monumentos. O Monumento Cascata (Figuras 6 e 7) desperta atenção por sua dimensão e beleza. Trata-se de uma cachoeira artificial, localizada na ala sul da praça, com uma queda-d'água que é representação simbólica da natureza e dos rios e cachoeiras do estado do Tocantins (ANJOS, 2017). Criado por João Devair, em parceria com a engenheira Lúcia Bacelar, esse monumento encontra-se na Praça dos Girassóis desde os anos 2000 e ocupa uma área de $1.200 \mathrm{~m}^{2}$, com pedras que simbolizam as formações rochosas da Serra do Carmo (TOCATINS, 2013).

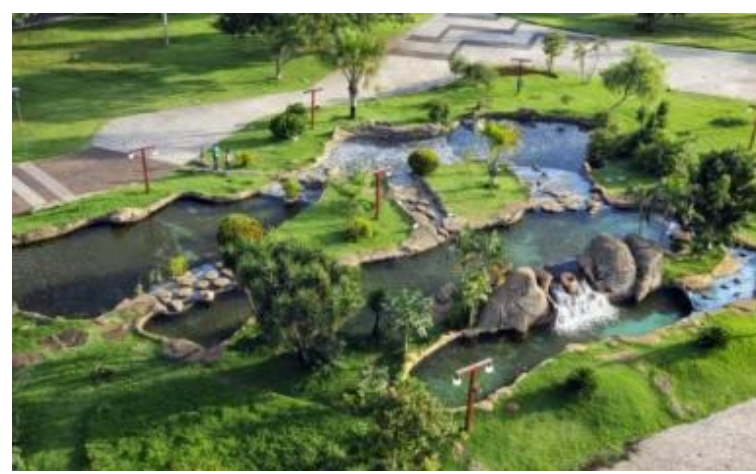

Figura 6 - Praça dos Girassóis: vista aérea do Monumento Cascata

Fonte: Secom - TO, 2019.

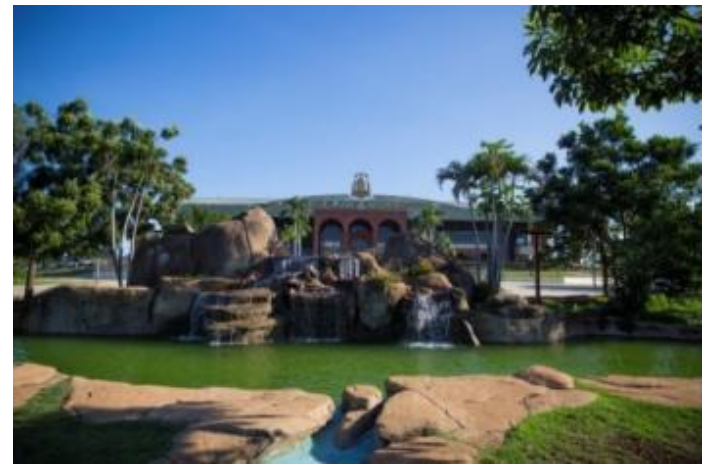

Figura 7 - Praça dos Girassóis: Monumento Cascata e o Palácio Araguaia

Fonte: Flávio André, 2019.

Já na terceira gestão governamental de Siqueira Campos (1999 a 2003), implantouse o Monumento Relógio do Sol (Figura 8), que foi inaugurado no dia 7 de setembro de 2000. Localizado próximo à entrada sul do Palácio Araguaia (Figura 9), esse monumento possui uma dimensão escalar de "seis metros de altura e sessenta metros de diâmetro, que é formado a partir do mostrador que fica no chão e é feito de pedras portuguesas", totalizando aproximadamente 700 metros quadrados (TOCANTINS, 2013, p. 19). 
Observando as curvas, podemos perceber a diferença entre o tempo solar aparente e o tempo civil em relação a cada época do ano. Outra parte fundamental neste tipo de relógio é o ponteiro ou estilete, que é fixo e tem quatorze metros de comprimento. O tubo, também chamado gnomo, está voltado para o sul e produz a sombra tão importante na sinalização das horas (TOCANTINS, 2013, p. 19).

A funcionalidade do Relógio do Sol destaca-se tanto durante o dia, por meio da sombra projetada pela haste, como à noite, como um observatório da constelação do Cruzeiro do Sul. Ressalta-se que, com o mostrado no chão da praça, é possível enxergar linhas que indicam as horas e os meses, na cor preta. $O$ monumento foi projetado e assinado pelo arquiteto Silêncio Martins Camargo, com parceria da "consultoria do físico do Observatório Nacional Marcomede Rangel Nunes" (TOCANTINS, 2013, p. 19).

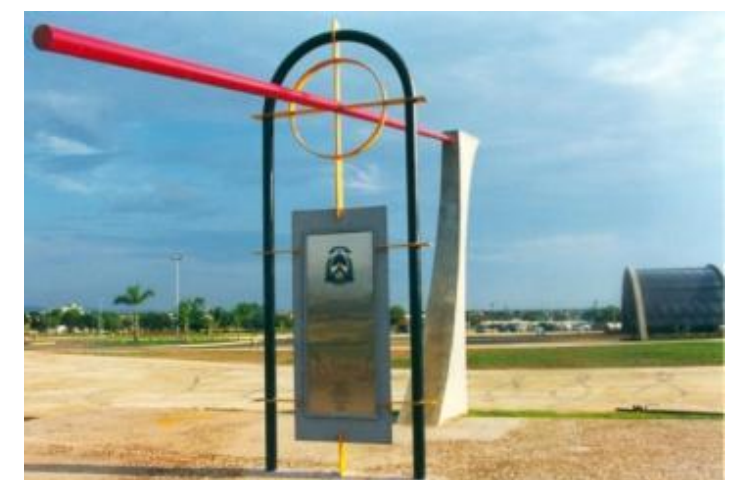

Figura 8 - Praça dos Girassóis: Monumento Relógio do Sol

Fonte: Kleiber Arantes, 2013.

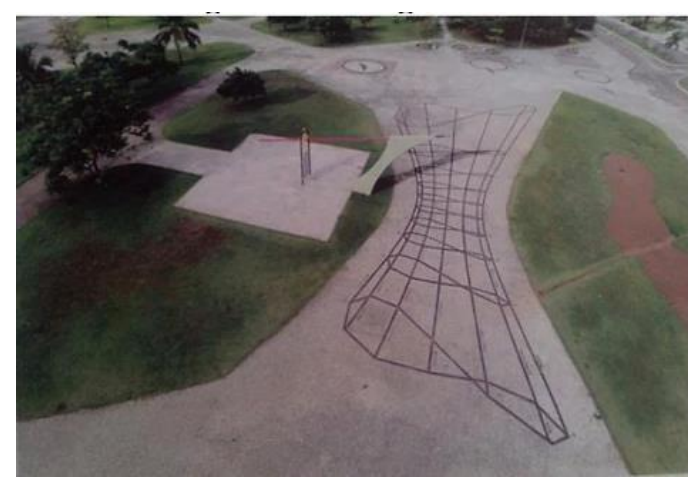

Figura 9 - Praça dos Girassóis: Monumento Relógio do Sol numa perspectiva aérea

Fonte: Anjos, 2017

$\mathrm{Na}$ ala norte, à frente da entrada principal do Palácio Araguaia, está o Monumento à Bíblia (Figura 10), produzido com material de granito escuro, instalado na Praça dos Girassóis em 10 de dezembro de 2000 (TOCANTINS, 2013). O monumento encontra-se edificado no centro da imagem da Rosa dos Ventos. Essa escultura monumental ocupa uma área aproximadamente de sete metros quadrados e tem o formato de dois braços estendidos aos céus sustentando a Bíblia sagrada. Nesta, encontra-se grafada a frase "Deus enviou seu filho não para condenar, mas para salvar o mundo" (BÍBLIA, João 3, 17). 


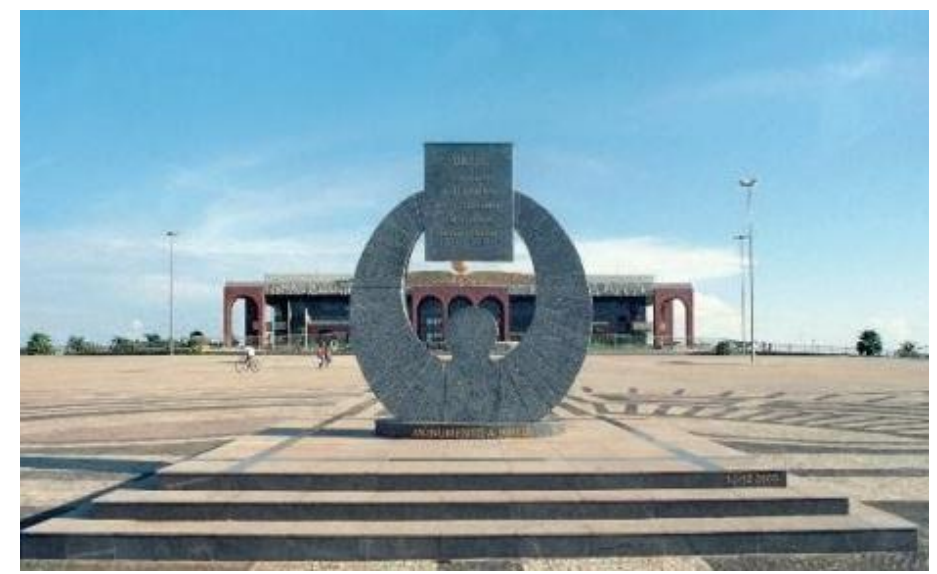

Figura 10 - Praça dos Girassóis: Monumento à Bíblia com inscrição de versículo bíblico e com o Palácio Araguaia, ao fundo Fonte. Secom - TO, 2004.

Na porção sudoeste da Praça dos Girassóis, situa-se o Monumento aos Dezoito do Forte de Copacabana (Figura 11), inaugurado em 5 de outubro de 2001 pelo então governador Siqueira Campos, e que, juntamente com o edifício monumental da Coluna Prestes, forma o complexo museológico histórico-cultural da Praça dos Girassóis (TOCANTINS, 2013).

O Monumento aos Dezoito do Forte de Copacabana é composto por dezenove esculturas de bronze que medem até $2,10 \mathrm{~cm}$ de altura, produzidas pelo artista plástico Maurício Bentes. "As estátuas estão dispostas sobre um calçamento com formas de onda, que tem por objetivo reproduzir as calçadas, em mosaico de pedra portuguesa, da Avenida Atlântica, local por onde marchou o movimento", em uma área de aproximadamente 1.638,04 metros quadrados (TOCANTINS, 2007, p. 10).

As esculturas representadas exibem a cena de batalha realizada pelo grupo de revoltosos. Em destaque, à frente do grupo, o tenente Antônio de Siqueira Campos conduz a bandeira do Brasil em retalhos e trêmula (Figura 12). Têm-se, ainda, soldados em posições estratégicas, feridos, caídos, e um civil simbolizando o fotógrafo que registra toda a cena de batalha. Na parte frontal do monumento, encontra-se uma frase grafada atribuída ao tenente Siqueira Campos, que diz: "À pátria tudo se deve dar, nada se deve pedir, nem mesmo compreensão', Tenente Siqueira Campos, herói dos '18 do Forte' e da Coluna Prestes" (TOCANTINS, 2007). 


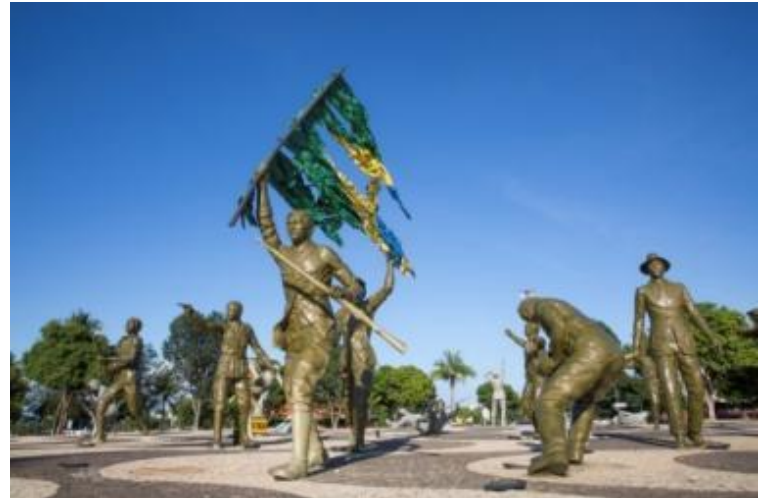

Figura 11 - Praça dos Girassóis: Monumento aos Dezoito do Forte de Copacabana

Fonte: Flávio André de Souza, 2018.

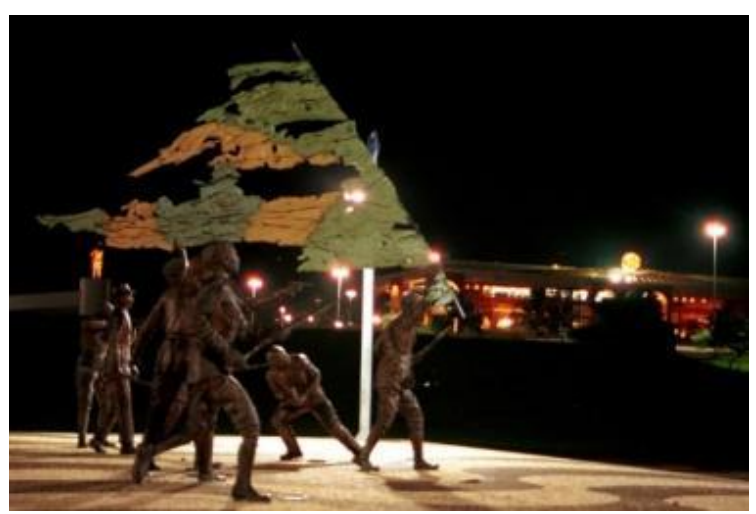

Figura 12 - Praça dos Girassóis: Monumento aos Dezoito do Forte de Copacabana e o Palácio Araguaia Fonte: Márcio Di Pietro, 2013

Na entrada principal da Praça dos Girassóis encontra-se o Monumento Súplica dos Pioneiros (Figura 13), uma obra do artista plástico Maurício Bentes, instalada em 18 de março de 2002 (TOCANTINS, 2013). Esse monumento fica em frente ao Memorial da Primeira Missa, o Cruzeiro, e é formado por nove personagens, feitos de bronze, que simbolizam os primeiros pioneiros que chegaram às terras do novo estado, caracterizados pelas figuras de um pai, uma mãe, filhos e filhas, e um animal, o carneiro, escolhido para expressar o sentimento religioso do povo tocantinense (TOCANTINS, 2013).

O monumento ocupa uma área de quase 68 metros quadrados, contendo esculturas que chegam a medir 2,36 metros de altura (maior escultura), e a menor possui apenas 71 centímetros. Nota-se que quatro personagens têm as mãos erguidas aos céus, como se estivessem fazendo referência ou agradecimento (Figura 14). Anjos (2017) ressalta que as esculturas estão todas com a face voltada para o lado leste, local onde nasce o sol.

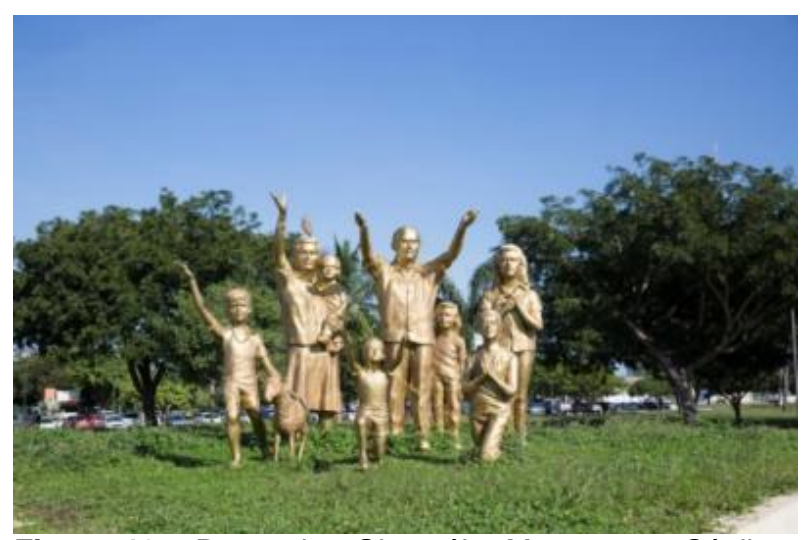

Figura 13 - Praça dos Girassóis: Monumento Súplica dos Pioneiros, perspectiva frontal

Fonte: Flávio André de Souza, 2018.

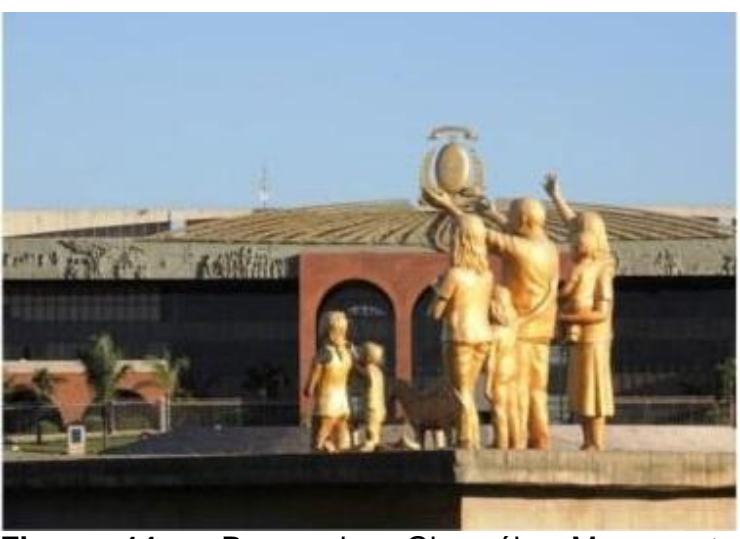

Figura 14 - Praça dos Girassóis: Monumento Súplica dos Pioneiros e o Palácio Araguaia Fonte: Anjos, 2017.

Dos seis monumentos descritos, considera-se, nesta análise interpretativa, quatro como os mais emblemáticos, a saber: o Cruzeiro, a Bíblia, os Dezoito do Forte de Copacabana e a Súplica dos Pioneiros. Atentando principalmente para os sentidos e os significados políticos, religiosos e identitários desses monumentos, por possuírem maior 
visibilidade dado a sua localização, que inclui o posicionamento em relação ao Palácio Araguaia, e por abarcar questões ideológicas vinculadas à construção dessas formas simbólicas que se associam aos contextos políticos vinculados ao ex-governador Siqueira Campos, mas com atribuição de sentidos variantes (CORRÊA, 2018).

\section{Os significados político-identitários dos monumentos cívico-religiosos da Praça dos Girassóis: o Cruzeiro, a Bíblia e a Súplica dos Pioneiros}

O Cruzeiro possui, em sua produção, significados que abarcam aspectos religiosos, políticos e identitários, haja vista que esse monumento é um símbolo de devoção e de poder extremamente reconhecido. Sua fixação na cidade de Palmas em 1989 marcou, não só o início da urbanização desse espaço, mas a construção da atual Praça dos Girassóis.

O local onde se erige o Cruzeiro é o mesmo que "se realiza a primeira Missa, considerada o batismo espiritual da cidade vindoura" (REIS, 2011, p. 114). A missa em questão foi celebrada pelo bispo de Porto Nacional, Dom Celson Pereira (Figura 15) (ANJOS, 2017), acompanhado pelos padres Juracy Cavalcanti, Rui Cavalcanti e pelo Monsenhor Jacinto Sardinha (REIS, 2011), com a presença de Siqueira Campos, o primeiro governador eleito. Ocorrida em 18 de maio de 1989, contou com massiva participação popular, principalmente de devotos católicos, indígenas Xerente e convidados oficiais.

Para Reis (2011), a prática ritualística da fixação de uma cruz em locais simbólicos remete, sobretudo, à primeira missa celebrada no Brasil, em Porto Seguro (BA), que teve a presença do frei Henrique Coimbra, também líder da cerimônia. A autora em questão pontua que "tais práticas se sustentam em ações passadas, de que extraem símbolos capazes de legitimar as ações do presente, como se ali estivessem desbravando novas terras e tomando posse do lugar" (REIS, 2011, p. 134).

Com isso, o local onde se fixa o Cruzeiro e se celebra a primeira missa na nova capital, molda uma narrativa poderosa, fazendo desse espaço um lugar de memória, "onde perpetuará a intenção do seu fundador, visto que o Cruzeiro muitas vezes é consagrado como monumento oficial da cidade" (REIS, 2011, p. 114). O cruzeiro torna-se desse modo, um "geossímbolo que identifica a cidade, tornando-se presente no seu cotidiano" (CORRÊA, 2018, p. 257).

ISSN: 2236-837X 


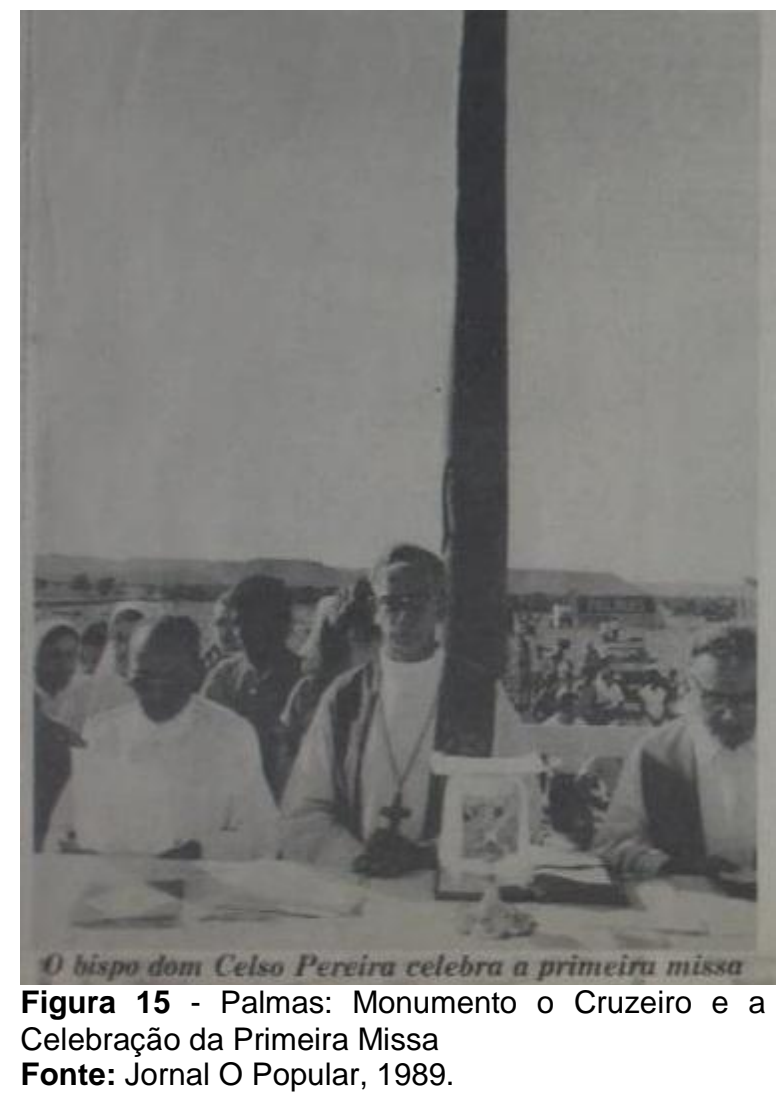

Em outro ângulo, as formas simbólicas espaciais estão igualmente vinculadas à identidade religiosa de uma nação ou de um grupo específico. Para Corrêa (2018), a escala dos monumentos simbólicos é correlata ao sentido e à importância atribuída à religião associada a esses marcos. Ademais, consideram-se os monumentos como portadores de sentidos políticos variáveis, uma vez que são construções edificadas por governos que visam reafirmar a identidade religiosa individual ou de um povo.

De acordo com Rodrigues (2008, p. 76), os grupos políticos hegemônicos "possuem um papel fundamental no sentido de elaborar símbolos, discursos e falas na intenção de produzir uma leitura de mundo a ser disseminada entre os governados". Nesse aspecto, a inclusão de elementos religiosos torna-se um recurso de poder, uma vez que quem produz essas representações atuam sobre a "produção de símbolos já incorporados pela sociedade, tratando apenas de atribuir uma nova 'roupagem' e significados a ela" (RODRIGUES, 2008, p. 76). De forma mais específica, o Monumento do Cruzeiro é estabelecido na tentativa de reforçar e territorializar uma crença já estabelecida em escala nacional, que é a do catolicismo.

Tradicionalmente, símbolos e representações fazem parte do cotidiano social. Ao tratar de uma simbologia religiosa, o Cruzeiro é o símbolo mais emblemático para as religiões católicas. Seu significado rememora o local do sacrifício feito por Jesus Cristo. A cruz é, então, um símbolo poderoso que reflete na identidade católica do povo brasileiro,

ISSN: 2236-837X 
que pode ser vista de acordo com Corrêa (2018, p. 257) "como parte da política de pressão e cooperação da Igreja Católica sobre o Estado reafirmando a visão do Brasil como um país católico", que busca expandir seu poder religioso e territorial pela representação simbólica desse monumento.

Ao passo que impõe uma crença religiosa sobre as demais, o Cruzeiro reafirma a autoridade religiosa na construção do Estado, objetivando reafirmar e gerar identificação, pertencimento, aos sujeitos ocupantes desse território. Imbui-se, portanto, de significados políticos, por ter sido concebido em um período de profundas transformações estatais, e com aspectos religiosos e identitários.

Rodrigues (2008) problematiza um conceito vultoso para a análise desse monumento de cunho religioso. O autor pontua que a hierofania está presente em todas as tradições religiosas, permitindo ao homem distinguir o espaço sagrado (extracotidiano) do espaço profano (cotidiano), o que representa "uma manifestação de alguma forma do sagrado e a determinação de um ponto fixo" (RODRIGUES, 2008, p. 95). A cruz, como símbolo religioso fixado na Praça dos Girassóis, torna-se, assim, um elemento sagrado. Visível em um espaço público, esse símbolo incorpora, ao seu local de estruturação, a sacralidade para aqueles que o reconhecem e para os que se identificam com a sua simbologia.

A construção do espaço sagrado nas ideias eliadianas ocorre por
meio de processos simbólicos que refletem as características
emocionais associadas às qualidades físicas do lugar, cuja
transformação pode ser dois tipos. O primeiro envolve a
manifestação direta da divindade, uma hierofania em certas coisas,
objetos ou pessoas. O lócus da hierofania reconhecido por
indivíduos ou grupos de crentes. No segundo tipo, o espaço é
ritualmente construído. Em ambos, o espaço sagrado contém dois
elementos fundamentais: o lócus da hierofania em seu entorno, que
constitui a área vivamente utilizada para o crente realizar suas
práticas religiosas e seu roteiro devocional (ROSENDAHL, 2012, p.
75).

A representação das mãos erguidas realçada na cruz sinaliza um agradecimento, fortalecendo ainda mais o sentido religioso do monumento, que o torna alegórico, significando vitória ou conquista. Esse simbolismo ratificado na inscrição dessa cruz rememora ao trecho bíblico que narra o conflito dos israelistas e amalequistas, que só foi vencido por conta das mãos erguidas de Moisés. O primeiro governador do estado, Siqueira Campos, utilizava-se comumente desse gesto corporal (Figuras 16 e 17) em seus comícios, eventos e celebrações. Sobre o gesto, Souza (2016, p. 141) pontua que "a comunicação não-verbal tem um valor simbólico especial que exprime, através de uma linguagem corporal elementar, atitudes sobre a imagem do comunicador".

ISSN: 2236-837X 


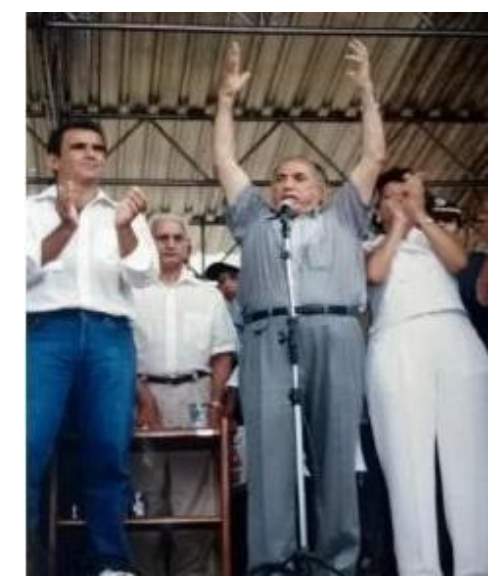

Figura 16 - Siqueira Campos: inauguração do Parque Cesamar em 1998 Fonte: Souza, 2016.

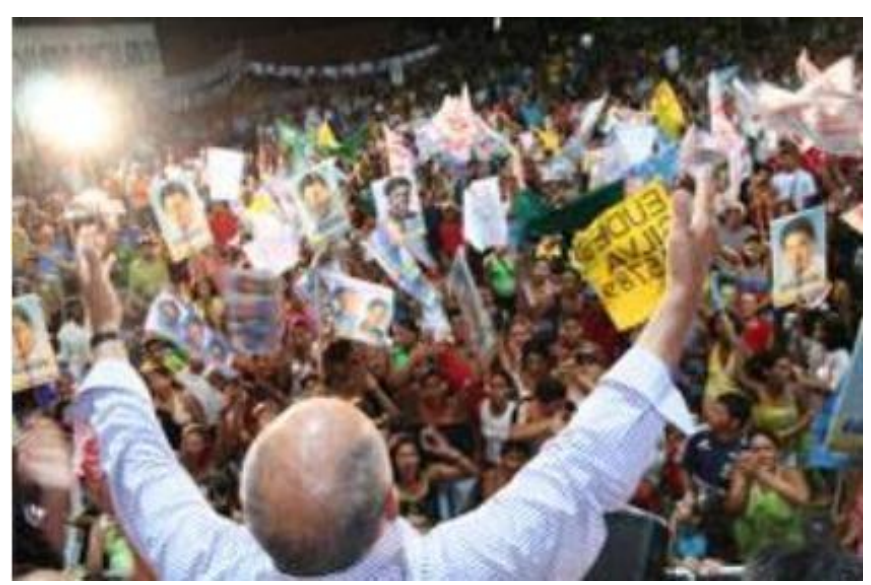

Figura 17 - Siqueira Campos: gesto corporal em destaque, 2006

Fonte: Souza, 2016.

Entende-se, portanto, que o Cruzeiro é mais do que um símbolo religioso, fixo, de teor representativo, pois visa, sobretudo, incorporar esse espaço edificado na Praça dos Girassóis como um lugar sacro consagrado. Torna-se, também, um espaço onde se reafirmar o poder dado ao primeiro governador, já que, por meio desse monumento, há um controle de significados que legitima a estrutura social associada (CORRÊA, 2018).

Posto isso, pode-se dizer que há a interposição de um monumento religioso em um espaço artificial e simbólico, envolvendo principalmente o símbolo mítico e remetendo ao rito religioso. Dessa forma, o Cruzeiro introduziu a produção de um "sistema simbólico" (BOURDIEU, 1989) que é evidenciado no espaço da Praça dos Girassóis.

De acordo com Rosendahl (2012, p. 74), "o sagrado irrompe em determinados espaços, qualificando-os em uma dimensão religiosa, além das dimensões econômicas, políticas e social que apresentam". Nessa análise, três monumentos dispersos pela Praça dos Girassóis apresentam-se imbuídos de particularidades nitidamente de caráter religioso, a saber: o Cruzeiro, a Bíblia e a Súplica dos Pioneiros.

De acordo com Brito (2010b, p. 81), "diferentemente do Cruzeiro, o monumento à Bíblia foi prestigiado por uma multidão de evangélicos, a maioria absoluta de pentecostais. Apenas o arcebispo, acompanhado por um padre e duas freiras, se fizeram presente na inauguração". Nesse aspecto, a participação de dois grupos de crenças divergentes na implantação desses monumentos religiosos confirma que essas formas simbólicas espaciais "estão, contudo, sujeitas a diferentes interpretações, caracterizando-se pela instabilidade de significados, pela plurivocalidade" (CORRÊA, 2018, p. 224).

Este monumento foi feito no momento em que os principais veículos de comunicação propagavam Palmas como capital evangélica do Brasil. Alguma relação pode ser tecida sobre o assunto, pois ao se construir um monumento no efervescer de uma discussão que coloca Palmas como capital evangélica criou-se uma resistência por

ISSN: 2236-837X 
parte do povo católico em aceitar o monumento como uma expressão apenas cristã; para estes o monumento era para os evangélicos (BRITO, 2010, p. 81).

Verifica-se que já ocorria um discurso político-religioso que enfatizava a cidade e, automaticamente, os sujeitos que a ocupam como evangélicos. A propagação desse discurso é materializada pela edificação dos monumentos supracitados. Portanto, é notável a tentativa de afirmar uma identidade religiosa por meio do espaço monumental edificado, que objetiva "representar valores como se fossem de todos" (CORRÊA, 2013, p. 74).

A representação do Monumento à Bíblia destaca-se pela simbologia de dois braços erguendo uma Bíblia para o alto, na qual está inserida a frase já supracitada do evangelho de João (BÍBLIA, João 3, 17). Assim como o Cruzeiro, o Monumento à Bíblia também enfatiza a representação de duas mãos erguidas. O que difere esse monumento do outro é o fato das mãos estarem segurando o livro bíblico, contudo, não deixa de existir correlação nestas duas representações monumentais.

Rodrigues (2008) argumenta que para tentar legitimar o poder político do grupo que governou o estado do Tocantins por quatro mandatos, houve a manipulação do imaginário e da criação de símbolos que possibilitassem a legitimação das ações de Siqueira Campos e seu grupo político no estado. Pelos monumentos descritos, é possível inferir, na construção de símbolos e bens religiosos, finalidade política. Assim, tanto a localização como a dimensão espacial desses monumentos controlam uma política de significados passíveis de emitirem mensagens almejadas por seus idealizadores. Como apontando por Corrêa (2013, p. 87), a localização "[...] é de fundamental importância, pois a visibilidade e acessibilidade ampliadas permitem a maximização da capacidade de comunicarem aquilo que deles se espera".

Toda forma simbólica visa expressar algum significado, uma vez que constituem traços fundamentais do comportamento humano. De acordo com Leach (1978, p. 59), "um signo ou símbolo somente adquire sentido quando é diferenciado de algum outro símbolo ou signo contrário". Nessa proposição, no intuito de satisfazer toda a população palmense, edificam-se dois monumentos que caracterizam os grupos religiosos: católico e evangélico, atribuindo-Ihes representação e simbologia. Assim, obtém-se reconhecimento e apreço popular desses grupos.

As ações de Siqueira Campos, como governador do estado que autoriza a implantação dessas formas simbólicas, estão de acordo com as reflexões apontadas por Baczko (1984), que indica que todas as ações sociais e de instituições políticas corroboram para afirmar e prolongar a existência humana. Por isso, edificam-se imagens e representações de si próprio e/ou de outros. O governo, por "possuir liberdade de ação e de escolha [...] compõe uma elite poderosa" (ROCHA, 2008, p. 141) que idealiza e edifica

ISSN: 2236-837X 
essas formas simbólicas, viabilizando que o espaço esteja impregnado de materialidade, fornecendo, por meios dessas formas, significados diversos, que são associados à "estética, status, etnicidade e sacralidade" (CORRÊA, 2019, p. 44).

O governo emprega sua autoridade para desenvolver autoafirmação a partir das formas simbólicas espaciais. Essa autoafirmação associa-se com os aspectos do cotidiano popular, podendo ser representações identitárias, religiosas ou políticas que proferem a soberania de atores hegemônicos sobre o território.

O território se forma a partir do espaço, é o resultado de uma ação conduzida por um ator sintagmático (ator que realiza um programa) em qualquer nível. Ao se apropriar de um espaço, concreta ou abstratamente (por exemplo, pela representação), 0 ator "territorializa" o espaço. Evidentemente, o território se apoia no espaço, mas não é o espaço. É uma produção, a partir do espaço [...] qualquer projeto no espaço é expresso por uma representação revela a imagem desejada de um território, de um local de relações (RAFFESTIN, 1993, 143 - 144).

Assim, a produção dos monumentos apresenta-se como o resultado das ações de Siqueira Campos, que se apropriou do espaço simbólico da Praça dos Girassóis para idealizar formas simbólicas espaciais que fixassem a sua imagem em associação ao território, no caso, o do estado do Tocantins e da cidade de Palmas. Enfatiza-se que essas produções simbólicas monumentais foram gestadas para compor uma identidade que necessitava ser construída, gerando uma integração social. Por outro lado, as mesmas visavam legitimar o grupo político idealizador destas.

$\mathrm{Na}$ medida em que o homem se apropria do território, tenta validar suas práticas e comportamentos elaborando símbolos que podem reproduzir o poder político outrora dado. Diante disso, os monumentos desta análise fazem parte de um sistema simbólico e agem como instrumentos de conhecimento e de comunicação. Desse modo, o poder simbólico, articulado às formas simbólicas espaciais, estabelece uma ordem em que estas são estruturadas para dar sentido ao mundo (BOURDIEU, 1989).

Logo, considera-se que os monumentos também foram idealizados no intuito de forjar identidades. Essa identidade é forjada a partir de monumentos com sentidos religiosos e políticos, principalmente com a instalação do Cruzeiro. No momento da implantação desse monumento se instaurava definitivamente um Estado, claramente delimitado e orquestrado, restando apenas que se fornecessem elementos identitários e operadores simbólicos que gerassem pertencimento aos novos habitantes do Tocantins e da cidade de Palmas. Dessa maneira, reconhece-se que a edificação de formas simbólicas espaciais manipula a elaboração de uma "comunidade imaginada" (ANDERSON, 2008), por meio de representações que se cristalizam no exercício da dominação política.

ISSN: 2236-837X 
Para essas duas representações monumentais (o Cruzeiro e a Bíblia) há um elemento de identificação popular, formado por representações sociais coletivas (DURKHEIM, 1996) passíveis de reconhecimento por toda uma comunidade, independente da crença. A representação de uma cruz e de uma bíblia pode ser facilmente identificada por qualquer indivíduo, sobretudo pelo fato de fazer parte de uma construção, logo, de um sistema simbólico nacional que envolve o poder religioso. Acrescenta-se a isso o fato de que o homem enquanto animal simbólico envolve-se "de tal modo em formas linguísticas, imagens artísticas, símbolos míticos ou ritos religiosos que não consegue ver ou conhecer coisa alguma a não ser pela interposição desse meio artificial” (CASSIRER, 2001, p. 48). Colabora, portanto, para a construção e moldura do espaço em detrimento próprio, por reconhecimento ou identificação.

Posto isso, a edificação desses monumentos é o resultado e a "consequência da ação de agentes sociais concretos, históricos, dotados de interesses, estratégias e práticas espaciais próprias, portadores de contradições e geradores de conflitos entre eles mesmos e com outros segmentos da sociedade" (CORREAA, 2019, p. 43). Conflitos que foram gerados e que ainda norteiam embates, dado a natureza religiosa desses monumentos em um espaço público democrático e laico. Como bem pontuou Brito (2010b), a aceitação pela edificação desses monumentos por parte da população gerou reações adversas, pincipalmente entre a comunidade religiosa da cidade, tais como católicos e evangélicos.

Com efeito, destaca-se que Siqueira Campos utilizou de seus interesses pessoais para instrumentalizar essas representações simbólicas, principalmente por se aproveitar de elementos religiosos que pudessem aproximar o poder político do imaginário popular, visto que, "ao produzir um sistema de representações que simultaneamente legitima sua ordem, qualquer sociedade instala também seus guardiões do sistema" (RODRIGUES, 2008, p. 74). Isso é, recai ao sistema simbólico o papel de fixação do representativo no imaginário social, uma vez que os sujeitos, ao interpretarem essas formas simbólicas como construções edificadas em determinado tempo histórico e, portanto, tempo político, poderão associá-las justamente com as ações de Siqueira Campos. Preserva-se e legitima-se, assim, as ações desse político para o devir da cidade, tornando-o um guardião do sistema.

A identificação desses simbolismos só é possível pelo poder associativo da memória e da identidade, ambas submetidas no campo das representações, como afirma Candau (2019). Nesse caso, a memória pode ser definida como a capacidade humana de "analisar as formas e como a mesma se manifesta (variável de acordo com os indivíduos, grupos, sociedades)" (CANDAU, 2019, p. 21).

As manifestações acerca dessas formas simbólicas analisáveis pelos sujeitos de um dado espaço são controladas por grupos detentores do poder. Ou seja, os símbolos são

ISSN: 2236-837X 
propositalmente elaborados. Da mesma maneira, Souza (2016, p. 140) afirma que "os símbolos de poder, de dominação se entrelaçam, propositalmente, com a perspectiva da memória do 'criador' nos diversos espaços da cidade". De certo, pode-se conferir aos monumentos a capacidade de produção, construção, ou invenção de memórias e de identidades. Com isso, as formas simbólicas da Praça dos Girassóis, e a própria praça, tornam-se lugares privilegiados de investimento do imaginário (BOURDIEU, 1989).

Como exposto, uma vez que as formas simbólicas espaciais podem conceber a identificação e a recordação de acontecimentos do preterido, e também incorporar significados que já são atribuídos à sua localização (CORRÊA, 2013), o governo utiliza-se dessas ferramentas para tornar o espaço uma "testemunha da memória das coisas fixadas na paisagem criada, o que possibilita a consolidação e produção de um espaço simbólico que reorganiza a cada instante os sentidos de objetos, lugares e pessoas" (SANTOS, 2008, p. 173).

Além disso, têm-se os significados atribuídos à simbologia do Monumento Súplica dos Pioneiros, que está à frente do Cruzeiro, representando uma família de possíveis retirantes que chegaram ao estado do Tocantins no início de sua fundação. As esculturas foram elaboradas por liga metálica (bronze) e que nas palavras de Corrêa (2018, p. 230) "os monumentos, fixos e duráveis, construídos, sobretudo com bronze, mármore ou granito congelam ideais e valores no espaço".

Das oito esculturas de representação humana, quatro estão com as mãos erguidas aos céus. Essa ação das mãos erguidas aos céus também é encontrada na inscrição presente nos monumentos Cruzeiro e Bíblia, como já exposto. As outras duas esculturas estão com mãos juntas, como se estivessem literalmente suplicando, agradecendo ou demonstrando submissão, evidenciado de modo literal comoção/súplica. Tem-se ainda a escultura de criança no colo, a de um animal (carneiro) e a de outra criança encostada na figura paterna do monumento.

De acordo com Adorno (2005), o Monumento Súplica dos Pioneiros reluziria o sentimento religioso do "povo tocantinense". O autor destaca que os personagens do monumento em questão evidenciam a autorrepresentação. Assim, existe "uma clara coincidência com as formas físicas, o número de filhos, o sexo e a faixa etária da família do então governador quando iniciava sua carreira política no então norte goiano" (ADORNO, 2005 , p. 207). A esse respeito, Silva et. al. (2013, p. 220) pontua que todos os filhos do exgovernador possuem "estátuas banhadas a pó de ouro italiano na Praça de Palmas, sendo assim, indícios claros de que a obra foi inspirada na tentativa de uma auto-representação, reforço de identidade e legitimação do político Siqueira Campos".

ISSN: 2236-837X 
O poder simbólico cravado nessa estrutura monumental é fortemente ideológico, tático e pujante, visto que representa valores esteticamente religiosos e se imbui de princípios políticos. Além disso, vincula a imagem dos pioneiros, com destaque para a representação de Siqueira Campos, ao campo religioso e sagrado. É nesse aspecto que o símbolo, construído e pensado como moldura para um determinado espaço, serve como um instrumento material que manifesta sentido, significado e atribuições. O monumento da Súplica dos Pioneiros legitima o discurso e as ações do primeiro governador do estado. É, sobretudo, uma tentativa de induzir suas práticas e ações no imaginário popular palmense e tocantinense. Destarte, esse monumento, por estar fixado ao lado do Cruzeiro e por caracterizar um sentimento religioso nas esculturas, corrobora para "construir um espelho de representação e legitimá-lo por meio da implantação de uma aura sagrada em torno de um objetivo meramente político" (RODRIGUES, 2008, p. 43).

\section{A forjadura dos significados político-identitários do Monumento aos Dezoito do Forte de Copacabana na Praça dos Girassóis}

Imbuído de caráter político, cívico e identitário, o monumento aos Dezoito do Forte de Copacabana apresenta-se como uma forma simbólica de fácil acessibilidade e de ampla visibilidade, devido à sua localização na Praça dos Girassóis. Esse monumento, construído em homenagem à revolta iniciada no Forte de Copacabana e finalizada com a marcha pela Avenida Atlântica, no Rio de Janeiro, em 1922, retrata o movimento tenentista, com destaque para o Tenente Antônio de Siqueira Campos, cujo sobrenome é homônimo ao do ex-governador do Tocantins já citado. Nesta presente análise, questiona-se: qual a relação histórica, política e cultural do movimento tenentista, sobretudo do episódio no Forte de Copacabana, com a cidade de Palmas e com o estado do Tocantins?

A narrativa histórica demonstra que não há nenhuma relação fortemente expressa que possibilite uma ligação entre essa revolta de 1922 com a capital do estado do Tocantins, implantada a partir de 1989. Para Brito (2010, p. 83), a construção desse monumento na Praça dos Girassóis "traz um sentimento de estranhamento da história do lugar".

Dito isso, verifica-se que o monumento aos Dezoito do Forte de Copacabana, edificado durante a gestão governamental de Siqueira Campos, pode ser interpretado "como uma forma simbólica cuja intenção daqueles que o conceberam e realizaram esforços para a sua construção era criar e difundir a identidade nacional a partir dos valores associados" (CORRÊA, 2018, p. 253) ao movimento tenentista. Mais do que isso, nesse monumento está a relação com a identidade nacional e o desejo de tornar os membros que

ISSN: 2236-837X 
participaram da revolta como heróis nacionais. Portanto, é o símbolo de um evento histórico que objetiva se estabelecer e manter continuidade na memória social por meio da edificação monumental.

Visto que o Tenente Siqueira Campos foi um dos combatentes que participaram da revolta e que sua escultura se encontra à frente das demais, segurando a bandeira do Brasil em retalhos, constata-se uma única relação plausível: a analogia nominal ao primeiro governador do estado. Em entrevista cedida para Sandoval Souza, Siqueira Campos narra que "o tenente Antônio de Siqueira Campos, um dos chamados 'heróis dos 18 do forte' era primo de seu pai" (SOUZA, 2016, p. 168). Destarte, salienta-se que essa informação não foi comprovada, tratando-se apenas de uma narrativa apresentada por Siqueira Campos em entrevista exclusiva.

A elaboração dessa forma simbólica e os elementos representativos emitidos pela ordem e posição dos soldados apresentados no monumento aos Dezoito do Forte de Copacabana, produzem a fabricação direta ou indireta de uma associação automática ao ex-governador Siqueira Campos. Essa ligação é descrita por Reis (2010) como uma estratégia do ex-governador para se manter eternamente presente na história do Tocantins, pelo destaque do evidente homônimo com o Tenente Antônio de Siqueira Campos.

Nas entrelinhas desse monumento, engendram-se os aspectos temporais de uma história inventada, construída e emoldurada. Corrêa (2019) nos aponta a possibilidade de se inventar uma memória. Para isso, utiliza-se da paisagem, que desempenha um papelchave, "exibindo cenas que transmitem mensagens sobre um passado que as elites desejam que sejam recriados e inventados, desse modo, as formas simbólicas espaciais constituem o veículo para essa transmissão" (CORRÊA, 2019, p.41).

Pode-se falar, portanto, da idealização do monumento aos Dezoito do Forte de Copacabana para agir de acordo com "as continuidades e as descontinuidades sobre as temporalidades e sobre o devir" da cidade (SEABRA, 2004, p. 185). Essas cadeias narrativas, edificadas por intermédio da construção dos monumentos que elaboram memórias, são formadas por conta da fragilidade identitária e cultural de uma cidade recente que necessita do poder de identificação para gerar pertencimento aos sujeitos. Mais do que isso, é uma investida política que fabrica uma "paisagem de simulação do passado, que transporta o observador a um passado que não existiu, criando uma memória seletiva e equivocada" (CORRÊA, 2019, p. 41).

A curta duração temporal do estado do Tocantins permite um controle simbólico que forja elementos identitários e políticos sobre o passado. O Monumento aos Dezoito do Forte de Copacabana, além de ser uma violência simbólica, é uma invenção representativa que

ISSN: 2236-837X 
possibilita a fixação de um personagem político para a continuidade e a permanência de suas ações na história da cidade de Palmas e do estado do Tocantins.

Dessa forma, deve-se falar desse monumento como uma edificação elaborada para tornar-se um lugar de memória. Segundo Corrêa (2018, p. 263), as "formas simbólicas que têm em suas manifestações matérias certos espaços públicos impregnados de significados em torno do passado e os memoriais de guerra" tornam-se lugares de memória que objetivam gerar continuidade histórica. Consagram-se também como monumentos incompletos que possibilitam interpretações diferentes, construindo, assim, significados que são criados e recriados. Portanto, esses espaços públicos que abrigam monumentos de memórias de guerra ou batalha, como o Monumento aos Dezoito do Forte de Copacabana, inserem-se no "discurso social a respeito do passado e na política de identidade coletiva, gerada e controlada por forças hegemônicas visando à consolidação e legitimação do poder que dispõem" (CORRÊA, 2018, p. 264).

Destacar ainda que, para esse monumento ter algum significado, necessita-se de sentidos que são apreendidos por quem os visualiza. Nesse aspecto, Rodrigues (2008) discorre que é apenas pela atribuição de sentidos a fatos, coisas e eventos que se ampliam a significação e o imaginário particular de cada sujeito. Da mesma forma, o Monumento aos Dezoito do Forte, juntamente com os outros monumentos descritos até aqui, são constructos de uma representação social para o devir, isto é, da imposição de uma memória coletiva que fica materializada no espaço de representação chamado de Praça dos Girassóis.

\begin{abstract}
A elaboração de um imaginário é parte integrante da legitimação de qualquer regime político. É por meio do imaginário que se podem atingir não só a cabeça, mas, de modo especial, o coração, isto é, as aspirações, os medos e as esperanças de um povo. É nele que as sociedades definem suas identidades e objetivos, definem seus inimigos, organizam seu passado, presente, futuro. O imaginário é constituído e se expressa por ideologias e utopias, sem dúvidas, mas também - e é o que aqui me interessa - por símbolos, alegorias, rituais, mitos. Símbolos e mitos podem, por seu caráter difuso, por sua leitura menos codificada, tornar-se elementos poderosos de projeção de interesses, aspirações e medos coletivos. (CARVALHO, 1990, p. 10 grifo nosso).
\end{abstract}

A incorporação simbólica do Monumento aos Dezoito do Forte de Copacabana, destacada particularmente pela escultura do Tenente Antônio de Siqueira Campos, configura-se como a tentativa de incluir no imaginário popular palmense a participação do ex-governador nesse movimento histórico, que se associa também ao da Coluna Prestes. Essas associações são plausíveis por aqueles que desconhecem a realidade e a história desses movimentos, tendo, portanto, a imagem do ex-governador Siqueira Campos

ISSN: 2236-837X 
integrada a esses movimentos políticos. Consequentemente, não descartam um interesse político que visa legitimar e fixar no estado e na capital uma narrativa construída por um sistema simbólico que surte efeito no imaginário social. De outro lado, há uma projeção que caracteriza o interesse pessoal do primeiro governador em manter sua imagem correlacionada a esse monumento, além da associação e da tentativa de difundir a identidade nacional a partir dos valores que rondam o movimento "tenentista". Desse modo, grupos políticos e a própria elite detentora do poder articulam valores reconhecidos nacionalmente para legitimarem um movimento e difundirem elementos identitários e de pertencimento.

Seguindo esses apontamentos, Reis (2010) consente que as memórias possam ser criadas por meio de lugares simbólicos edificados por ações do estado. Esses símbolos são previamente selecionados para se tornarem públicos, coletivizando a ideia de "identidades tocantinenses", ou construindo, dessa forma, a própria "História Oficial do Tocantins'” (REIS, 2010, p. 121). Siqueira Campos insere-se na história oficial desse estado utilizandose da produção monumental com o intuito de perpetuar sua atuação política, isto é, por meio da edificação de diversas formas simbólicas autorrepresentativas, religiosas e/ou políticas, dispersas pela Praça dos Girassóis. Outro exemplo disso é quando figura como autor da própria criação da capital e do estado do Tocantins.

\section{Considerações finais}

O espaço simbólico denominado Praça dos Girassóis, em Palmas, TO, assegura a manutenção de estratégias e práticas associadas aos aspectos políticos-identitários, religiosos e culturais, engendrados, sobretudo, pelas intervenções do primeiro governador do estado, José Wilson Siqueira Campos. Os monumentos formam uma espécie de complementariedade do discurso, com narrativas concebidas por simbolismos e forçadas a se encaixar, resultando no objetivo que se espera obter pelas representações desse espaço.

Por meio dos monumentos Cruzeiro, Bíblia e Súplica dos Pioneiros, validam-se as acepções religiosas, que são expressas por intermédio da iconografia, dos símbolos e das frases religiosas inscritas nos próprios monumentos. Ratificam-se, por outro lado, os intentos políticos, juntamente com o monumento aos Dezoito do Forte de Copacabana, que foram edificados durante as gestões de Siqueira Campos, bem como a tendência de transformar a memória política tradicional em historiografia oficial (FIRMINO, 2003).

Na tentativa de firmar e emoldurar sua participação na construção e na formação da cidade de Palmas e do estado do Tocantins, Siqueira Campos utiliza-se da Praça dos

ISSN: 2236-837X 
Girassóis e de seu conjunto monumental para cunhar seu domínio político e se atar no imaginário social local. Desse modo, cria-se uma continuação do passado, que é representado nas formas simbólicas espaciais fixas. Posto isso, "o devir pode ser pensado, ao menos em relação a certo lapso de tempo, garantida a permanência de práticas espaciais e da inércia espacial" (CORRÊA, 2019, p. 48). Uma vez fixados, esses monumentos permanecem emitindo significados, que serão garantidos enquanto houver visibilidade.

Nessa perspectiva, devido à curta duração da história da capital e do estado, há uma necessidade de fabricação de identidades culturais, inventadas e forjadas no processo de transformação urbana, por meio do qual os monumentos concebem paisagens dotadas de inúmeros símbolos. Preenchem-se, ademais, com "signos portadores de mensagens ideológicas, que contribuem para cumprir a tarefa de modelar o imaginário social gerando a formação de imagens do passado e do futuro, criando e alterando padrões de significados" (PEET, 1996, p. 23).

Ora, tais apontamentos sobre esses monumentos remetem à noção de "tradições inventadas", expressão consagrada por Hobsbawn e Ranger (2002), e que, nesta análise, é apreendida como:

[...] um conjunto de práticas, normalmente reguladas por regras tácita ou abertamente aceitas; tais práticas, de natureza ritual ou simbólica, visam inculcar valores e normas de comportamento através da repetição, o que implica, automaticamente, uma continuidade com o passado (HOBSBAWN; RANGER, 2002, p. 9).

Destaca-se que durante a construção da Praça dos Girassóis e, consequentemente, de seus monumentos, a presença e o controle do ex-governador Siqueira Campos sempre se fez presente (REIS, 2011). O manifesto controle simbólico desse espaço, com a exaltação ao ex-governador, evidencia-se como criações monumentais, construídas de "modo artificial, visando dá continuidade ao passado" (HOBSBAWM, 2002, p. 13) e concebidas por um único ator social.

Segundo Corrêa (2018), esses monumentos criados de modo bastante artificial, que dão continuidade ao passado, são edificados como consequência das rápidas e amplas transformações que ocasionam na incapacitação do uso e na adaptação de velhas tradições. $O$ autor ainda discorre que, entre essas transformações, destacam-se os conflitos sociais de classes e de religião, derivadas das mudanças decorrentes da ascensão e queda de estados totalitários.

O estabelecimento dessas chamadas tradições inventadas aplica-se pela artificialidade dos cenários criados, ou ainda na investida de legitimar instituições, status ou grupos de autoridades, na medida em que "o espaço e o tempo desempenham papéis

ISSN: 2236-837X 
diferentes em relação ao devir simbólicos das estátuas, obeliscos, e memoriais, dessas formas criadas o que materializam como sendo tradições inventadas" (CORREAA 2018, p. 230). Desse modo, as tradições inventadas são configuradas pela investida de tentar inovar o passado por meio da releitura do presente.

Os significados e as interpretações dadas aos monumentos são contestáveis, sendo, assim, suscetíveis à polivocalidade. A intenção do seu idealizador pode não ser compreendida e analisada por aqueles que observam os monumentos, da mesma forma que, ao longo do tempo, essas representações podem se tornar "arcaicas e irrelevantes" (OSBORNE, 1998, p. 434), como resultado das ações temporais e das mudanças nos valores políticos e religiosos que permitem a alteração do modo de ver e de analisar o espaço edificado.

Para Brito (2010, p. 88), as formas simbólicas na Praça dos Girassóis expressam, com precisão, um consenso religioso, mas também político "[...] representa o poder que intentaram impor sobre a capital para construir" uma memória e uma história um período curto de tempo. Por outro lado, o grupo político associado e vigente no período dessas construções forjou um sistema simbólico impregnado de sentidos e significados incorporado ao passado e projetado para o futuro. Esse grupo político que deteve o poder estadual teve a persona de Siqueira Campos como o articulador das façanhas representativas dispostas na Praça dos Girassóis. Tais formas simbólicas conservam enunciados que envolvem os temas: identidade, poder, memória e religião. Sendo essas formas "fixas e de longa duração, que contêm a intenção de articular, no momento de sua concepção, o passado ou o futuro, estabelecendo a continuidade de um tempo social" (CORRÊA, 2018, p 235).

No bojo de uma história tecida pelas mãos de Siqueira Campos, figura principal na elaboração dos monumentos, a Praça dos Girassóis torna-se um espaço emblemático de representações condutoras de mensagens com cunho nitidamente político, religioso e identitário. Nesse processo de estruturação que contou com ideais políticos, os monumentos edificados historiam experiências que visam ser fixadas no espaço entrelaçado ao tempo.

Da análise realizada, ressaltam-se os sentidos atribuídos aos monumentos Cruzeiro, Súplica dos Pioneiros, Bíblia e Dezoito do Forte de Copacabana, que foram construídos durante as gestões do ex-governador Siqueira Campos e fazem parte de um "processo de seletividade simbólica, indicando caráter aberto, passiveis de apropriação em diferentes direções e propósitos" (CORRÊA, 2018, p. 253).

Ademais, e como já evidenciado, as interpretações acerca desses monumentos são múltiplas, exatamente pela polivocalidade que cada um expressa. Contudo, os sentidos são ostensivos para se compreender as intenções e os sentidos atribuídos aos citados

ISSN: 2236-837X 
monumentos. Dessa forma, nota-se que esses monumentos expressam a construção de uma memória para o futuro, associada à imagem do primeiro governador do estado, exibindo simbolismos de autorrepresentação e, portanto, de autoafirmação política. Somado a isso, instaura-se um sistema de valores atrelados ao grupo político associado que idealizou a edificação das formas simbólicas analisadas.

Essas atribuições também fazem parte dos significados analisados no Monumento Súplica dos Pioneiros, que expressa autoafirmação, especialmente pelo uso das esculturas que destacam a família do ex-governador, além de manifestar elementos inspirados pela religiosidade, destacados pelo uso das mãos erguidas aos céus, tal como o Monumento à Bíblia. O Monumento Súplica dos Pioneiros acentua novamente a autorrepresentação para inculcar valores e atribuir significados. Já no Monumento aos Dezoito do Forte de Copacabana, a analogia entre o tenente Siqueira Campos (RJ) e o político Siqueira Campos (TO) comprova a elaboração de uma tessitura para o devir, para a construção de uma história, ou mais, para inserção de um personagem em um fato histórico que não lhe é concernente.

Essas características atuam no imaginário popular, na identidade cultural de um povo e no sistema de valor social. Dessa maneira, torna-se imprescindível destacar que todo monumento possui sentido político. Com essa prerrogativa, Siqueira Campos engendra um sistema simbólico de representações espaciais para perpetuar sua imagem e sua história como primeiro governador no estado. Essas representações da realidade resultam em um processo por meio do qual os significados são criados e comunicados (HALL, 1997), passíveis de contradições ou reafirmações, trajando intentos lançados na longa duração, no sentido de perdurar o devir da capital do estado de Tocantins.

\section{Agradecimentos}

Agradecemos à Coordenação de Aperfeiçoamento de Pessoal de Nível Superior (CAPES) pela concessão da bolsa de mestrado, a qual possibilitou a realização desta pesquisa. Agradecemos também ao historiador Rivair Tavares Morais, do Memorial Coluna Prestes, por ceder, por meio de seu acervo pessoal, grande parte da documentação utilizada para a produção do artigo.

\section{Referências}

ADORNO, L. F. M. Cultura, território e identidade na América latina: forjando uma geografia turística por uma geografia política. In: X Encontro de Geógrafos da América Latina, 2005, São Paulo. Anais... São Paulo: USP, 2005. p. $198-210$. 
ANJOS, A. C. C. Do girassol ao capim dourado: apropriação e ressignificação de elementos naturais na narrativa identitária do Estado do Tocantins. Porto Alegre: Editora Fi, 2017.

ANDERSON, B. Comunidades imaginadas: reflexões sobre a origem e a difusão do nacionalismo. 2. ed. São Paulo: Companhia das Letras, 2008.

BACZKO, B. Imaginação social. In: Enciclopédia Einaudi. Antropos-Homem. Lisboa: Imprensa Nacional, Casa da Moeda, 1984, p. 296 - 332.

BALANDIER, G. O poder em cena. Brasília: UNB, 1982.

BÍBLIA, Antigo Testamento. Êxodo. Bíblia de Estudo: Batalha Espiritual e Vitória Financeira: Antigo e Novo Testamento. Tradução de Maria Eugencia da Silva Fernandes. Rio de Janeiro, 2007.

BRITO, E. P. Do Sol que gira (o Tempo) aos Girassóis (o Espaço). Revista Entre-Lugar. Dourados, v.1, n¹, p. 99-112, 2010a.

BRITO, E. P. Construir Palmas? Uma análise da construção da capital do Tocantins. Revista Ateliê Geográfico, Goiânia, v.4, n. 4, p. 74-90, 2010b.

BOURDIEU, P. O Poder Simbólico. 11. ed. Rio de Janeiro: Bertrand Brasil, 1989.

CANDAU, J. Memória e identidade. 1. ed. São Paulo: Contexto, 2019.

CASSIRER, E. Filosofia das formas simbólicas I - a linguagem. 1. ed. São Paulo: Martins Fontes, 2001.

CARVALHO, J. M. Formação das almas. 0 imaginário da república no Brasil. Companhia das Letras. 1990.

CORRÊA, R. L. Formas simbólicas e espaço - algumas considerações. Aurora geography jornal. Rio de Janeiro. v.1, n¹, p. 178 - 195, 2007.

Espaço e Simbolismo. In: CASTRO, I. E.; GOMES, P. C. C. (orgs.). Olhares geográficos: modos de ver e viver o espaço. Rio de Janeiro: Bertrand Brasil, 2012, p. 133 - 153.

Monumentos política e espaço. In: ROSENSAHL, Z. (org.). Geografia Cultural: uma antologia, volume II. Rio de Janeiro: EdUERJ, 2013, p. 73-100.

Caminhos paralelos e entrecruzados. São Paulo: UNESP, 2018.

Sobre agentes sociais, escala, produção do espaço: Um texto para discussão. In: A produção do Espaço Urbano. Agentes e processos, escalas e desafios. CARLOS, A. F. A.; SOUZA, M. L; SPOSITO, M. E. B. (orgs.). 1 ed. São Paulo: Contexto 2019.

CHOAY, F. A alegoria do patrimônio. São Paulo, 2001.

DIAS, P. Cruzeiro é reinstalado na Praça dos Girassóis. Assembleia Legislativa do Tocantins, 2016. Disponível em: https://al.to.leg.br/noticia/6326/cruzeiro-e-reinstalado-na-praca-dos-girassois. Acesso em: 26 nov. 2020.

DURKHEIM, E. As Formas Elementares da Vida Religiosa. São Paulo: Martins Fontes, 1996.

FIRMINO, E. P. M. Ensino de História, Identidade e ideologia: A experiência do Tocantins. 2003.285 f. Dissertação (Mestrado em Educação Brasileira) - Faculdade de Educação, Universidade Federal de Goiás, Goiânia, GO, 2003.

HOBSBAWN, E. A invenção da tradição. RANGER, T.. (Org.). São Paulo, Paz e Terra, 2002.

ISSN: 2236-837X 
HARTOG, F. Régimes d'historicité: présentisme et expériences du temps. Paris: Seuil, 2003.

NORA, P.. Between Memory and History: Less Lieux de Memoire. Representations, v. 26, n 7, p. 7$24,1989$.

PEET, R. A sing taken for history: Daniel Shays Memorial in Oetershamm, Massachusetts. Annals os the Association of American Geographers, v. 86, n¹, p. $21-43,1996$.

REIS, P. O. B. Modernidades Tardias no cerrado: discursos e práticas na história de Palmas TO (1990 - 2010). 2011. 227 f.Tese. (Doutorado em História) - Instituto de Filosofia e Ciências Sociais, Universidade Federal do Rio de Janeiro, Rio de Janeiro, 2011.

LEACH, E. Cultura e comunicação: a lógica pela qual os símbolos estão ligados. Rio de Janeiro: Jorge Zahar, 1978.

LE GOFF, J. História e Memória. São Paulo: Unicamp, 2003.

LOWENTHAL, D. "Past time, presente place: landscape and memory". Geographical Review, n65.v.1, p. $1-36$, , 1975.

MCCANN, F. Soldados da Pátria: história do Exército brasileiro, 1889 - 1937. São Paulo, Companhia das Letras, 2007.

NUNES, J. C. A. P. A gênese do movimento tenentista e o "primeiro 5 de julho": Memórias do "revolucionário" Delso Mendes da Fonseca. In: $30^{\circ}$ Simpósio Nacional de História, ANPUH-Brasil, Recife, 2019. Anais [...]. Recife- UFPE, 2019, p 1- 17.

OSBORNE, B. Constructing Landscape of power: the George Etienne Cartier Monument. Journal of Historical Geography, Montreal, v. 24, n¹, p. 431-458, 1998.

PALMAS. Decreto no 22, de 29 de fevereiro de 2000 . Dispõe sobre o tombamentoprovisóriodebensmunicipaisedáoutrasprovidências. Disponível em: https://legislativo.palmas.to.gov.br/media/leis/DECRETO\%20N\%C2\%BA\%2022 2000\%20de\%202902-2000\%2010-26-16.pdf. Acesso 20 dez. 2020

RAFFESTIN, C. Por Uma Geografia do Poder. São Paulo: Ática, 1993.

ROCHA, M. I. C. Estado e Governo: Diferença Conceitual e Implicações Práticas na PósModernidade. Revista Brasileira Multidisciplinar, v. 2, p. 140-145, 2008.

RODRIGUES, J. C. Estado do Tocantins: política e religião na construção do espaço de representação tocantinense. 2008. Tese. 148 f. (Doutorado em Geografia) - Faculdade de Ciência e Tecnologia - Universidade Estadual Paulista, Presidente Prudente, São Paulo, 2008.

Espaço, política e identidade cultural no Estado do Tocantins, Brasil. Pensamento e Imaginação Geográfica. In: XII Colóquio Ibérico de Geografia, 2010, Porto - PT. Anais [...] Faculdade de Letras, Universidade do Porto, 2010.

ROSENDAHL, Z. O Sagrado e sua dimensão espacial. In: CASTRO, I. E.; GOMES, P. C. C; CORRÊA, R. L. (orgs.). Olhares geográficos. Modos de ver e viver o espaço. Rio de Janeiro, Bertrand Brasil, 2012, p. 73 - 99.

SANTOS, M. Por uma geografia nova. Da crítica da Geografia a uma Geografia Crítica. São Paulo: Edusp, 2008.

SEABRA, O. C. L. Território do uso: cotidiano e modo de vida. Cidades, São Paulo, v.1. n², p. 181 206, 2004.

ISSN: 2236-837X 
SOUZA, S. A. O Siqueirismo no Tocantins: uma filosofia de vida para conduzir o povo a seu destino de grandeza. 2016. Tese. 216 f. (Doutorado em Sociologia) - Programa de Pós-graduação em Sociologia, Universidade Federal do Ceará, Fortaleza, 2016.

SILVA, E. M. et. al. Uma praça e "seus girassóis": As narrativas imagéticas da História de Palmas. In: COSTA, C; BUITONI, D. S. A. (orgs.). A cidade e a imagem. Jundiaí - São Paulo: In House, 2013, p. 207-227.

TOCANTINS. Inventario - Aos 18 do forte de Copacabana. Governo do Estado do Tocantins, Secretaria da Cultura - Fundação Cultural, 2007.

TOCANTINS. Secretaria de Estado de Cultura. Tocantins, seus símbolos, seu povo, sua história. A Praça dos Girassóis. Palmas - TO, 2013. 